\title{
APPLICATION OF SALMONELLA PHAGE COCKTAIL TO CONTROL SALMONELLA TYPHIMURIUM IN VITRO
}

\author{
Yasmer S. Hussein; Kh. A. El-Dougdoug and B.A. Othman \\ Agricultural Microbiology Dept. Fac. of Agric., Ain Shams Univ., Cairo, Egypt
}

Keywords: Salmonella Typhimurium, Sewage drain water, lytic bacteriophages, phage properties and biological control

\section{ABSTRACT}

Members of the genus Salmonella are among the microbial pathogens associated with dangerous infection. The increased of Salmonella spp. antibiotic resistance has propelled the need of alternate therapeutic methods or strategies. Bacteriophage forms one of these alternate strategies. Six lytic bacteriophages infecting Salmonella Typhimurium were isolated from sewage drain water. Phages were purified biologically by single plaque assay and concentrated using the ultracentrifugation. The phage isolates were named $\varnothing \mathrm{SM}, \varnothing \mathrm{SF}$, $\varnothing \mathrm{SG}, \varnothing \mathrm{SP}, \varnothing \mathrm{SA}$ and $\varnothing \mathrm{SD}$. Morphological characters of Salmonella phages showed that all the phage isolates belong to family Myoviridae. All phage isolates were highly stable at room temperature, storage at refrigerator temperature and had thermal inactivation point ranged from 90 to 98 ${ }^{\circ} \mathrm{C}$. Phages were stable at $\mathrm{pH}$ conditions ranging from $\mathrm{pH} 4$ to 12. Phages did not lose their infectivity after exposure to UV for $90 \mathrm{~min}$. at $35 \mathrm{~cm}$ and $53 \mathrm{~cm}$ distance. The host range of the isolated phages was found that the phages had narrow host range. Phage cocktail with different $\mathrm{MOI}$ was used to control Salmonella Typhimurium in vitro. Data revealed that addition of phage cocktail at MOI 10 reduced the Salmonella cells with rate 98.2 $\%$ after $4 \mathrm{hrs}$. from addition.

\section{INTRODUCTION}

Salmonella spp. belong to family Enterobacteriaceae and widely distributed in nature and often found in the intestinal tract of warmblooded animals and humans,where they asymptomatically colonize and multiply (Newell \& Fearnley, 2003 and Doyle \& Erickson, 2006).
More than 2,500 serotypes of Salmonella exist and the most prevalent and important Salmonella enterica serotypes reported worldwide are Enteritidis and Typhimurium. These are responsible for $99 \%$ of Salmonellosis in humans and warm-blooded animals. The most common symptoms of Salmonella infection is non-bloody diarrhea and abdominal cramps (Bell and Kyriakides, 2002). Due to foodborne infections by Salmonella are obtained through ingesting contaminated food or water, (Abd El-Aziz, 2013 ) detected high incidence of Salmonella Typhimurium , one of the most frequently isolated serovars from food borne outbreaks throughout the world, in retail raw chicken meat and giblets in Egypt.

Bacteriophages are considered an effective weapon against pathogenic bacteria. As a result of development resistant bacteria against antibiotics because of their repeated usage, bacteriophages are used as a safe alternative to control pathogenic bacteria (Abramia et al 2016). In addition, offer a great advantage over antibiotics. First, bacteriophages are specific and target only the pathogens of interest, so the normal gut microflora are not affected. Second, bacteriophages are self-replicating in the bacterial host and lyse bacteria. (Connerton and Connerton, 2005).

This paper aims to investigate the incidence of lytic bacteriophages specific for Salmonella in sewage water and study the posibility of their application for controling the Salmonella in vitro.

\section{MATERIALS AND METHODS}

\section{Source of the bacteria}

Salmonella enterica subsp. enterica serovar Typhimurium ATCC25566 was obtained from Microbiological Resources Center, Cairo Mircen, Fac. of Agric., Ain Shams Univ., Cairo, Egypt. 


\section{Sources of bacteriophages}

Eight different sewage drain water samples were collected as described in Table (1).The obtained samples were taken in sterile glass bottle of $250 \mathrm{ml}$ capacity and directly transferred to the Virology Lab., Agric. Microbiol. Dept., Fac. of Agric., Ain Shams Univ. The samples were maintained at $4{ }^{\circ} \mathrm{C}$ until needing for isolation of the phages.

\section{Isolation of Salmonella virulent phages}

Erlenmeyer flask $250 \mathrm{ml}$ containing $50 \mathrm{ml}$ of nutrient broth medium was inoculated with $5 \mathrm{ml}$ of overnight liquid culture of Salmonella and $5 \mathrm{ml}$ of the sewage drain water sample. The flasks were incubated at $37^{\circ} \mathrm{C}$ for $48 \mathrm{hrs}$. with shaking (250 $\mathrm{rpm} / \mathrm{min})$. After incubation the cultures were centrifuged at $6000 \mathrm{rpm}$ for $15 \mathrm{~min}$ at $4^{\circ} \mathrm{C}$. The supernatant was collected into a clean flask. Chloroform was added at rate of $1: 10$ to the supernatant followed by vigorously handle shaking for $5 \mathrm{~min}$. to remove any bacterial debris and small contaminated bacteria. The supernatant was collected as a crude phage lysate by obtaining the upper layer and removing the white lower layer according to (Borrego et al 1987).

\section{Detection of Salmonella phages}

The presence of bacteriophages specific for Salmonella was detected in the crude phage lysates qualitatively by the spot test according to (Borrego et al 1987). Bacteriophages were assayed quantitatively in the positive samples by the plaque assay method according to (Adams, 1959).

\section{Preparation of the phage lysates}

Phage lysates were prepared by single plaque isolation technique (Othman, 1997). Based on the morphological shape of plaques characters, different plaques were picked up and added to $3 \mathrm{ml}$ of the liquid culture of Salmonella. The cultures were incubated at the optimum conditions. The cultures were centrifuged to obtain the progeny phages. The process was repeated at least three times until obtaining uniform plaque morphology.

\section{Propagation of Salmonella phages}

After obtaining the phage lysates, single plaque isolation was done, a large amount of high titer phage stock was obtained by propagation the phage isolates on their liquid Salmonella culture according to (Goodridge et al 2001).

\section{Purification and concentration of Salmonella phages}

The propagated Salmonella phage isolates were concentrated using the ultracentrifugation method as following: the phage lysates were centrifuged at low speed $6000 \mathrm{rpm}$ for $15 \mathrm{~min}$. at $4^{\circ} \mathrm{C}$ to precipitate bacteria, and the supernatants were transferred to clean centrifuge tubes. The supernatants were centrifuged using Backman L 7-35 ultracentrifuge at $30000 \mathrm{rpm}$ for $90 \mathrm{~min}$. under cooling, then supernatants were carefully decanted and pellets were re-suspended in $300 \mu \mathrm{l} \mathrm{CM}$ buffer $\left(6 \mathrm{ml} / \mathrm{L} \quad 1 \mathrm{M}\right.$ Tris buffer; $2.5 \mathrm{~g} / \mathrm{L} \quad \mathrm{MgSO}_{4} .7 \mathrm{H}_{2} \mathrm{O}$; $0.735 \mathrm{~g} / \mathrm{L} \mathrm{CaCl} 2 ; 0.05 \mathrm{~g} / \mathrm{L}$ gelatin; $\mathrm{pH} 7.5)$, transferred into sterilized tube (Figrski and Christensen, 1974).

\section{Characterization of the isolated Salmonella phages}

\section{Microscopic examination}

One drop of Salmonella phage suspension was placed onto 200 mesh carbon coated cupper grid and allowed to adsorb for approximately $20 \mathrm{~min}$. The excess liquid was removed with filter paper wick. The grids were negatively stained with $2 \%$ (w/v) phosphotungstic acid for 90 seconds and left for drying, and then examined using a JOEL-JEM 1010 electron microscope (Electron Microscope Unit, Regional Center for Mycology and Biotechnology, Al-Azhar Univ., Cairo, Egypt ) (Othman, 1997).

\section{Thermal inactivation points (TIP)}

Thermal inactivation point of Salmonella phage isolates in vitro was carried out by exposure the phage suspension to different temperature degrees $30,40,50,60,70,80,90$ and $98 \stackrel{\circ}{\circ}$ for 10 min using controlled water bath and then directly cooled using ice water. $15 \mu \mathrm{l}$ from each treated phage was assayed qualitatively using the spot test according to (Basdew and Laing, 2014).

Storage of Salmonella phages 
The infectivity of Salmonella phages were examined qualitatively by spot test weekly after incubation at room temperature for 60 days and at $4^{\circ} \mathrm{C}$ for 60 days.

\section{pH stability}

The infectivity of phages to be active at different $\mathrm{pH}$ levels was evaluated by exposure the phage suspensions to adjusted $\mathrm{pH}$ values ranged from 4 to 12 using $0.1 \mathrm{M} \mathrm{HCl}$ or $\mathrm{NaOH}$ for 12 and $24 \mathrm{hrs}$ at room temperature according to (Taj et al 2014). After incubation of phage lysates were neutralized and the activity was determined by spot test method at $37^{\circ} \mathrm{C}$ for $24 \mathrm{~h}$.

\section{UV irradiation}

Stability of the isolated phages to different distances and times to UV irradiation was assayed qualitatively after exposure to UV wave length (254 $\mathrm{nm}$ ) for $15,30,45,60,75$ and $90 \mathrm{~min}$. at distance of $35 \mathrm{~cm}$ and for 30,60 and $90 \mathrm{~min}$. at distance of $53 \mathrm{~cm}$ from the UV lamp according to (Feisal et al 2013). The infectivity of the treated particles was determined, qualitatively.

\section{Host range pattern}

Agar double layer plates were used for host range assay. Each of the available bacteria belonging to Salmonella spp. were used as indicator bacteria in individual plates. The surface of every plate was spotted with drops of the isolated Salmonella phage lysates. After incubation for $24 \mathrm{hrs}$, plates were examined for clearance at the sites where the drops of phage had been applied as performed by (Rattanachaikunsopon and Phumkhachorn, 2012).

\section{Controlling Salmonella pathogen in vitro}

The bacterial challenge test was done with some modifications according to (Kocharunchitt et al 2009) using broth culture from Salmonella Typhimurium in an exponential phase to obtain an optical density at $600 \mathrm{~nm}, \mathrm{OD}_{600}$, of 0.560 $\left(\sim 10^{7} \mathrm{cfu} / \mathrm{ml}\right)$. Then, the broth culture was diluted to obtain $10^{6} \mathrm{cfu} / \mathrm{ml}$. The cocktail of phage lysates (consisting of six phage isolates) was added to the broth culture to obtain different multiplicity of infection (MOI) $0.01,0.1,10$ and 100. The experiment was done in vitro as follows: the previous mixture (2-replicates re-incubated at $25^{\circ} \mathrm{C}$ for $12 \mathrm{~h}$ ). Tworeplicates of bacterial cultures (containing only bacteria) and two-replicates of bacteriophages cultures (containing only bacteriophages) used as a negative control, tryptone soy broth was used instead of phage or bacteria in control treatments. Bacterial broth and streptomycin mixture was used as a positive control.

For counting Salmonella, aliquots of the treatment were taken and serially diluted in buffer peptone water, and $1 \mathrm{ml}$ from dilutions was counted using pour plate count method on Salmonella Shigella agar (S.S. agar) medium (Oxoid, 2006). After incubation at $37^{\circ} \mathrm{C}$ for $24 \mathrm{~h}$, Salmonella colonies were counted visually and used to calculate Salmonella numbers (cfu/ml in experiment samples). To count bacterial numbers to assess the changes in their titer, samples were taken at 0, 4, 8 and 12 hours (at the end of this experiment). The percent of bacterial reduction was done by the following formula: Percent reduction $=(A-B) \times 100 / A$, where $A$ is the number of viable microorganisms before treatment and $B$ is the number of viable microorganisms after treatment. To count phage cocktail numbers to assess the changes in their titer, samples were taken at $0,4,8$ and 12 hours (at the end of this experiment) like bacteria, then centrifuged at $6000 \mathrm{rpm} / 15 \mathrm{~min}$., precipitated bacteria by chloroform using 1:10 ratio and kept in the refrigerator for 2 hours at $4^{\circ} \mathrm{C}$. Then phage titer was determined by using plaque assay technique. Control samples were taken at 0 time and every 4 hours in bacteria but at 0 time and the end of the trial in phage.

\section{RESULTS AND DISCUSSION}

\section{Incidence of Salmonella lytic phages in water}

The primary nature habitat of Salmonella spp. is the intestinal tract of warm-blooded animals and humans. Salmonella spp. are also widespread in soil and water, as a result of their occurrence have been detected in irrigation water as a potential preharvest source of vegetables contamination by Salmonella (ljabadeniyi et al 2011). Salmonella Typhimurium phage was isolated from sewage water from Shoubra EL-Kheima, Elkalubia, Egypt (Feisal et al 2013). It is well known that where over you find the bacterial host, you find its bacteriophage. So different sewage drain water were collected to detect and isolate specific lytic Salmonella phages. Data in this investigation obtained by the spot test (Fig. 1 A) revealed that 6 samples out of 8 samples gave positive results as shown in (Table 1). 


\section{Lytic phage isolates}

All bacteriophage positive samples were assayed quantitatively using the plaque assay technique. Then, single plaque isolation was done to obtain pure Salmonella phage isolate according to (Othman, 1997). Only one plaque was picked up from each bacteriophage positive sample. The results was recorded in (Table 2 ) and illustrated in (Fig 1B), showed that all isolated phages have plaques with circular, clear shape with diameter ranged between 1 and less than $1 \mathrm{~mm}$ except phages $\varnothing$ SG and $\varnothing$ SD which have circular turbid plaque. Data agreed with (De Lappe et al 2009) who obtained also small $(\leq 1 \mathrm{~mm})$ circular plaques, belonged to Myoviridae but with an exception his plaques were without halo.

After single plaque isolation was done, $200 \mathrm{ml}$ of high titer phage stock was obtained by phage propagation several times the on its liquid bacterial culture. Then, The Salmonella phage particles were purified and concentrated using the ultracentrifugation.

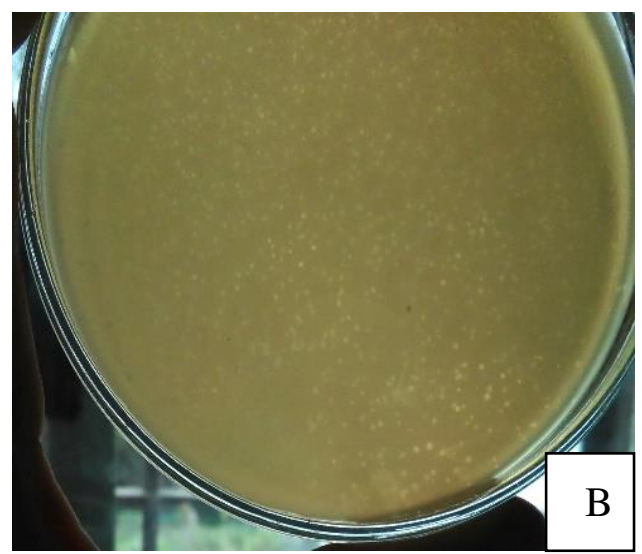

Fig. 1. (A) Spot test showing the bacterial lysis through the bacterial lawn caused by virulent bacteriophage specific for $S$. Typhimurum.

(B) Single plaques of $S$. Typhimurum phage showing identical morphology of the original plaques.

Table 1. Detection of Salmonella lytic phages in sewage drain water by the spot test

\begin{tabular}{|l|c|c|}
\hline \multicolumn{1}{|c|}{ Location } & \multicolumn{2}{c|}{ Salmonella phage assaying } \\
\cline { 2 - 3 } & Qualitatively & $\begin{array}{c}\text { Quantitatively } \\
\text { pfu/ml }\end{array}$ \\
\hline El-Esmailia canal, Mostorod, Elkalubia, Egypt & $(-)$ & - \\
El-Maryotya canal, Giza ,Egypt & $(+)$ & $2.5 \times 10^{5}$ \\
Fac. of Agriculture, Shoubra Elkhema, Elkalubia, Egypt & $(+)$ & $5 \times 10^{4}$ \\
Fac. of Agriculture, Shoubra Elkhema, Elkalubia, Egypt & $(-)$ & - \\
Fac. of Agriculture, Shoubra Elkhema, Elkalubia, Egypt & $(+)$ & $7 \times 10^{5}$ \\
El-Gabl El-Asfar - El-Khanka, Elkalubia, Egypt & $(+)$ & $5 \times 10^{5}$ \\
Passous. Elkalubia, Egypt & $(+)$ & $4.3 \times 10^{4}$ \\
Shoubra Elkhema station of sewage water, Elkalubia, Egypt & $(+)$ & $4 \times 10^{5}$ \\
\hline
\end{tabular}


Table 2. Plaque morphology of the isolated Salmonella phages

\begin{tabular}{|c|c|c|l|}
\hline Phages $^{*}$ & $\begin{array}{c}\text { Diameter } \\
\mathbf{( m m )}\end{array}$ & $\begin{array}{c}\text { Pres- } \\
\text { ence } \\
\text { of halo }\end{array}$ & Plaque shape \\
\hline$\varnothing \mathrm{SM}$ & $<1$ & + & clear, circular \\
$\varnothing \mathrm{SF}$ & $<1$ & + & clear, circular \\
$\varnothing \mathrm{SG}$ & 1 & + & turbid, circular \\
$\varnothing \mathrm{SP}$ & $<1$ & + & clear, circular \\
$\varnothing \mathrm{SA}$ & $<1$ & + & clear, circular \\
$\varnothing \mathrm{SD}$ & $<1$ & + & turbid, circular \\
\hline
\end{tabular}

* $\varnothing \mathrm{SM}=$ sewage drain water sample from El-Maryotya canal

* $\varnothing \mathrm{SF}=$ sewage drain water sample from poultry farm, Fac. of Agriculture, Shoubra Elkhema.

* $\varnothing \mathrm{SG}=$ sewage drain water sample from El-Gabl ElAsfar - El-Khanka.

* $\varnothing \mathrm{SP}=$ sewage drain water sample from Passous.

* $\varnothing \mathrm{SA}=$ sewage drain water sample from Fac. of agriculture, Shoubra Elkhema.

* $\varnothing \mathrm{SD}=$ sewage drain water sample from Shoubra Elkhema station of sewage water.

+ plaque was surrounded with halo

The six isolated Salmonella phages named $\varnothing$ SM, $\varnothing \mathrm{SF}, \varnothing \mathrm{SG}, \varnothing \mathrm{SP}, \varnothing \mathrm{SA}$ and $\varnothing \mathrm{SD}\left(\right.$ The $1^{\text {st }}$ letter means phage, the $2^{\text {nd }}$ letter means Salmonel$l a$ and the $3^{\text {rd }}$ letter means the first of isolation source).

\section{Characterization of Salmonella phages}

\section{Morphological characters}

As shown (Table 3) and illustrated by (Fig. 2), examination of the isolated Salmonella phages showed that phage $\varnothing$ SM has a head with diameter of $109.1 \times 109.1 \mathrm{~nm}$ and long contractile tail with length of $145.5 \mathrm{~nm}$ and width of $27.3 \mathrm{~nm}, \varnothing$ SF has a head with diameter of $77 \times 92.3 \mathrm{~nm}$ and long contractile tail with length of $153.8 \mathrm{~nm}$ and width of $23.1 \mathrm{~nm}, \varnothing \mathrm{SG}$ has a head with diameter of $107.1 \times 107.1 \mathrm{~nm}$ and long contractile tail with length of $164.3 \mathrm{~nm}$ and width of $21.4 \mathrm{~nm}, \varnothing \mathrm{SP}$ has a head with diameter of $92.9 \times 92.9 \mathrm{~nm}$ and long contractile tail with length of $157.1 \mathrm{~nm}$ and width of $21.4 \mathrm{~nm}$. $\varnothing \mathrm{SA}$ has a head with diameter of $109.1 \times 100 \mathrm{~nm}$ and long contractile tail with length of $163.6 \mathrm{~nm}$ and width of $18.18 \mathrm{~nm}$ and $\varnothing$ SD has a head with diameter of $118.2 \times 127.3 \mathrm{~nm}$ and long contractile tail with length of $172.7 \mathrm{~nm}$ and width of $27.3 \mathrm{~nm}$. The phages assigned to family Myoviridae as indicated by the presence of a long tail and occurrence of contractile sheath. All Salmonella phages reported belong to the order Caudovirales (tailed phages) and represent three families: the Siphoviridae, Podoviridae and Myoviridae. Data agreed with (Turner, 2012 and Thung et al 2017).

Table 3. Morphological characters (head and tail diameters) of Salmonella phages:

\begin{tabular}{|c|c|c|}
\hline \multirow{2}{*}{ Phage } & \multicolumn{2}{|c|}{ Size $(\mathbf{n m})$} \\
\cline { 2 - 3 } & Head & Tail \\
\hline$\varnothing \mathrm{SM}$ & $109.1 \times 109.1$ & $145.5 \times 27.3$ \\
$\varnothing \mathrm{SF}$ & $77 \times 92.3$ & $153.8 \times 23.1$ \\
$\varnothing \mathrm{SG}$ & $107.1 \times 107.1$ & $164.3 \times 21.4$ \\
$\varnothing \mathrm{SP}$ & $92.9 \times 92.9$ & $157.1 \times 21.4$ \\
$\varnothing \mathrm{SA}$ & $109.1 \times 100$ & $163.6 \times 18.18$ \\
$\varnothing \mathrm{SD}$ & $118.2 \times 127.3$ & $172.7 \times 27.3$ \\
\hline
\end{tabular}

\section{Physical properties}

Various external physical: temperature, acidity and salinity were affected on the viability and storage of bacteriophages. It can inactivate the phage through damage of its structural elements (head, tail, and envelope), lipid loss, and/or DNA structural changes (Ackermann et al 2004).

\section{Thermal inactivation point}

The particles of Salmonella phage were exposed to different degrees of temperature (range between 30 to $98^{\circ} \mathrm{C}$ ) for $10 \mathrm{~min}$, then cold immediately under the ice water to determine the thermal inactivation point. Results indicated that the thermal inactivation point of the phages $\varnothing \mathrm{SM}, \varnothing$ SF, $\varnothing \mathrm{SG}, \varnothing \mathrm{SP}, \varnothing \mathrm{SA}$ and $\varnothing \mathrm{SD}$ was $98^{\circ} \mathrm{C}, 98$ ${ }^{\circ} \mathrm{C}, 98{ }^{\circ} \mathrm{C}, 90{ }^{\circ} \mathrm{C}, 90{ }^{\circ} \mathrm{C}$ and $90{ }^{\circ} \mathrm{C}$ respectively, it was also indicated that the phages $\varnothing \mathrm{SM}, \varnothing \mathrm{SF}$ and $\varnothing$ SG were more stable after thermal treatment at $98^{\circ} \mathrm{C}$ for $10 \mathrm{~min}$., while phages $\varnothing \mathrm{SP}, \varnothing$ SA and $\varnothing$ SD lost their infectivity. Phages $\varnothing \mathrm{SP}, \varnothing$ SA and $\varnothing$ SD were still had the ability to lyse Salmonella after thermal treatment at $90{ }^{\circ} \mathrm{C}$ for 10 $\mathrm{min}$. The previous results proved that all Salmonella phages are thermal tolerant agreed with (Turner, 2013) who mentioned that bacteriophages infecting serovars of Salmonella enterica showed identical thermal tolerance profiles and still can be detectable after incubation at $70 \stackrel{\circ}{ } \mathrm{C}$ for 120 minutes. 

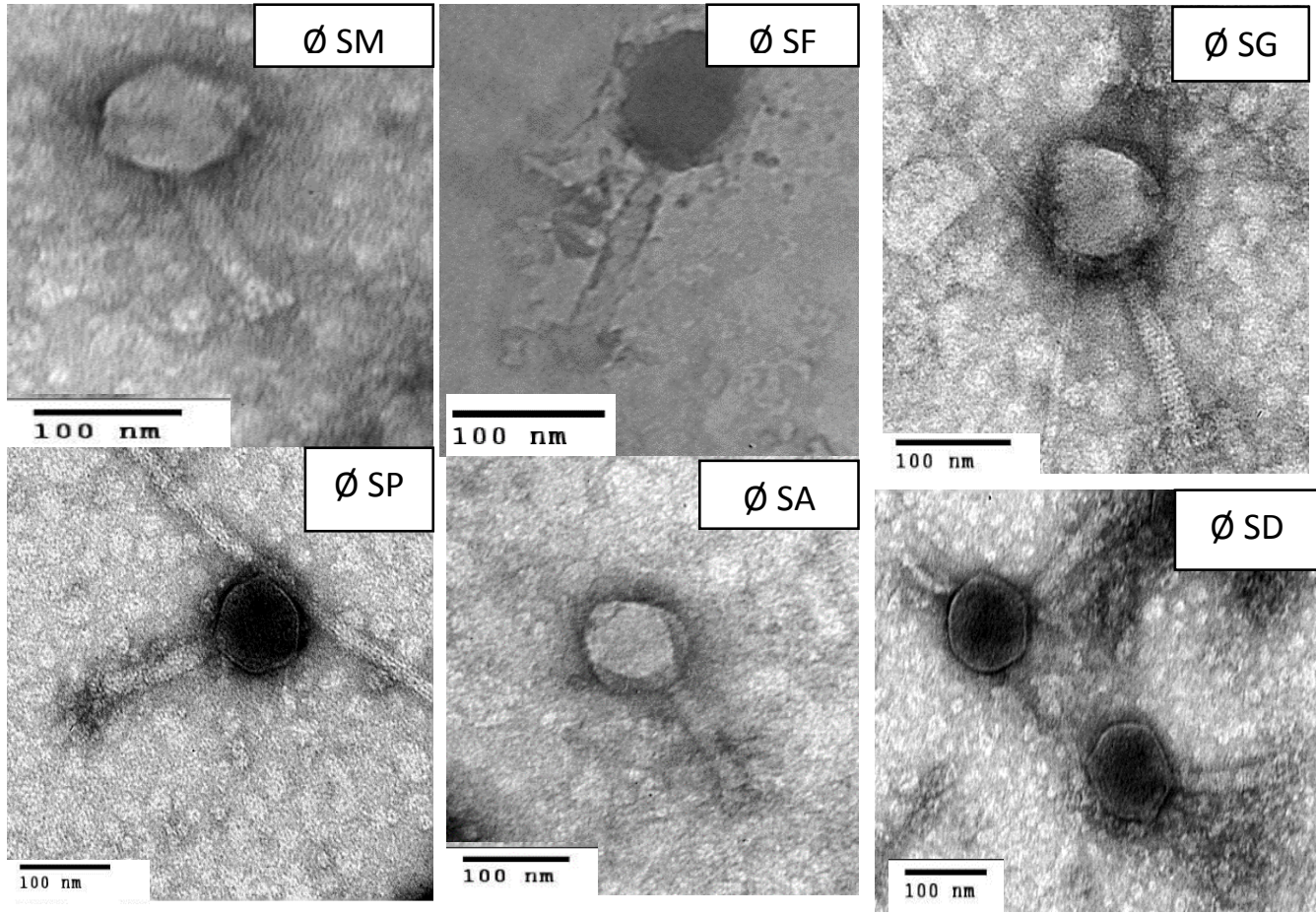

Fig. 2. Electron photograph of Salmonella phages ( $\mathrm{SM}, \varnothing \mathrm{SF}, \varnothing \mathrm{SG}, \varnothing \mathrm{SP}, \varnothing \mathrm{SA}$ and $\varnothing \mathrm{SD}$ ) negatively stained with $2 \%$ phosphotungstic acid by TEM.

\section{Storage of S. Typhimurium phages}

The aim of this trial was to assay the infectivity of phage particles in preserved food products stored at room temperature and refrigerator. It was found that Salmonella phages were survived for at least 60 days at room temperature and $4{ }^{\circ} \mathrm{C}$, when the viral infectivity was assayed qualitatively weekly by the spot test. The Salmonella phages have high stability until 60 days at different temperature degrees at room temperature and $4{ }^{\circ} \mathrm{C}$. Data agreed with (Ngangbam and Devi, 2012) who studied the effect of different temperatures on the viability of Salmonella phages during storage and the titer of his phage which had good a storage stability, was almost unaltered during 14 days of storage at $37^{\circ} \mathrm{C}, 4^{\circ} \mathrm{C}$, and $-20^{\circ} \mathrm{C}$.

\section{Acid and alkaline stability}

Infectivity of the isolated Salmonella phages was tested at different $\mathrm{pH}$ values. The viral infectivity was determined qualitatively by the spot test technique. The obtained results revealed that, all Salmonella phages didn't lose its ability to lyse $S$. Typhimurium cells at $\mathrm{pH}$ ranged from 4 to 12 . The results indicate that the $S$. Typhimurium phages are stable in both the alkaline media and acidic ones. Data agreed with (Kanjana, 2007) who reported that, STP Salmonella phage lost its inactivity and didn't detect after the treatment with $\mathrm{pH} 2$ and 3 , and however the STP phage remained infectious after treatment with $\mathrm{pH}$ 4-12.

\section{UV irradiation stability}

Salmonella phage particles were exposed to UV irradiation at 2 different distances far from it. They are at $35 \mathrm{~cm}$ from the UV source for 15,30 , 45, 60, 75 and 90 min., and 30,60 and 90 min. at $53 \mathrm{~cm}$ distance from the UV source. Salmonella phages didn't lose their infectivity after exposure at the different distances for the different times. The results didn't agree with (Feisal et al 2013), but (Jończyk et al 2011) stated that tailed phages like Salmonella phages were the most stable in adverse conditions. In addition to phages with a large capsid (100 nm in diameter) survive better than phages with a head $60 \mathrm{~nm}$ in diameter.

\section{Host range}

Six bacterial strain, serotypes and isolates belonging to $S$. Typhimurium , $S$. Paratyphi B and $S$. 
Typhi were tested against the infection with the isolated $S$. Typhimrium phages. Host specificity of the bacteriophage was assayed qualitatively by the spot test. Results as shown in (Table 4) indicate that, the isolated bacteriophages were able to lyse most of them. This result means that, the isolated Salmonella phages have a restricted host range. Results agreed with (Tiwari et al 2013) who determined host range of phage SE2, Salmonella strains of several serovars and non-Salmonella strains were used. Phage SE2 showed a strong lytic effect to all tested Salmonella isolates, Enteritidis and Gallinarum It did not form any plaque to other Salmonella serovars and non-Salmonella bacteria ( $E$. coli, K. pneumonia, $P$. aeruginosa, $A$. baumannii and $S$. aureus ).

\section{Controlling of Salmonella by its specific phag- es}

In vitro experiments were performed to evaluate the ability of Salmonella phage cocktail (mix- ture) to lyse $S$. Typhimurium. When phage cocktail was added to the host at MOI 0.01 , numbers of the host cells were reduced after $4 \mathrm{hrs}$ from the addition by $83.33 \%$, after 8 hrs by $89.44 \%$ and after 12 hr by $95 \%$. When phage cocktail was added the host at MOI 0.1 , numbers of the host cells were reduced after $4 \mathrm{hrs}$ after the addition by $83.93 \%$, after 8 hrs by $93.85 \%$ and after 12 hr by $98.80 \%$. When phage cocktail was added to the host at MOI 10 , numbers of the host cells were reduced after 4 hrs from the addition by $98.20 \%$, after 8 hrs by $99.93 \%$ and after $12 \mathrm{hr}$ by $99.99 \%$.When phage cocktail was added to the host at MOI 100, numbers of the host cells were reduced after $4 \mathrm{hrs}$ from the addition by $99.14 \%$, after 8 hrs by $99.99 \%$ and after $12 \mathrm{hr}$ by $99.99 \%$ as shown in (Table 5). The reduction of Salmonella numbers were also accompanied by increases in phage counts $4 \mathrm{hrs}$ after the phage cocktails addition, suggesting that the phage replicated. Streptomycin inhibited the growth of Salmonella when was used as a positive control.

Table 4. Host specificity of the isolated Salmonella phages

\begin{tabular}{|c|c|c|c|c|c|c|}
\hline Host specificity $\quad$ Phages & $\varnothing S M$ & $\varnothing \mathrm{SF}$ & $\varnothing S G$ & $\varnothing \mathrm{SP}$ & $\varnothing S A$ & $\varnothing \mathrm{SD}$ \\
\hline $\begin{array}{l}\text { S. Typhimurium* } \\
\text { NCTC12023/ ATCC } 14028\end{array}$ & + & + & + & + & + & + \\
\hline S. Typhimurium LT2** & + & + & + & + & + & + \\
\hline S. Typhimurium U288** & - & - & - & - & - & - \\
\hline S. Typhimurium DT160** & + & + & + & + & + & + \\
\hline S. Paratyphi B isolate* & + & + & + & + & + & + \\
\hline S. Typhi isolate ${ }^{\star *}$ & - & - & - & - & - & - \\
\hline
\end{tabular}

* Bacterial cultures were obtained from Agric. Microbiol. Dept., Fac. of Agric., Ain Shams Univ.

** Bacterial cultures were obtained from Animal Health Research Institute

Table 5. Effect of different phage multiplicity of infection on the growth of Salmonella in vitro

\begin{tabular}{|c|c|c|c|c|c|c|c|c|c|c|c|c|}
\hline \multirow{3}{*}{$\begin{array}{c}\text { Time } \\
\text { hr. }\end{array}$} & \multicolumn{3}{|c|}{ MOI 0.01} & \multicolumn{3}{|c|}{ MOI 0.1} & \multicolumn{3}{|c|}{ MOI 10} & \multicolumn{3}{|c|}{ MOI 100} \\
\hline & \multirow{2}{*}{\begin{tabular}{|l|} 
Control \\
$\mathrm{cfu} / \mathrm{ml}$ \\
\end{tabular}} & \multicolumn{2}{|c|}{ Treated } & \multirow{2}{*}{\begin{tabular}{|l|} 
Control \\
$\mathrm{cfu} / \mathrm{ml}$ \\
\end{tabular}} & \multicolumn{2}{|c|}{ Treated } & \multirow{2}{*}{\begin{tabular}{|l|} 
Control \\
cfu/ml
\end{tabular}} & \multicolumn{2}{|c|}{ Treated } & \multirow{2}{*}{\begin{tabular}{|l|} 
Control \\
cfu/ml \\
\end{tabular}} & \multicolumn{2}{|c|}{ Treated } \\
\hline & & cfu/ml & \begin{tabular}{|c} 
\% reduc- \\
tion
\end{tabular} & & cfu/ml & $\begin{array}{c}\% \text { reduc- } \\
\text { tion } \\
\end{array}$ & & $\mathrm{cfu} / \mathrm{ml}$ & \begin{tabular}{|c|}
$\begin{array}{c}\text { \% reduc- } \\
\text { tion }\end{array}$ \\
\end{tabular} & & $\mathrm{cfu} / \mathrm{ml}$ & $\begin{array}{c}\% \text { reduc- } \\
\text { tion }\end{array}$ \\
\hline 0 & & $5 \times 10^{6}$ & - & & $4.3 \times 10^{6}$ & & & & & & & \\
\hline 4 & $6 \times 10^{7}$ & $1 \times 10^{7}$ & $83.33 \%$ & $5.6 \times 10^{7}$ & $9 \times 10^{6}$ & $83.93 \%$ & $5 \times 10^{7}$ & $9 \times 10^{5}$ & $98.20 \%$ & $5 \times 10^{7}$ & $4.3 \times 10^{5}$ & $99.14 \%$ \\
\hline 8 & $7.1 \times 10^{8}$ & $7.5 \times 10^{7}$ & $89.44 \%$ & $6.5 \times 10^{8}$ & $4 \times 10^{7}$ & $93.85 \%$ & $6.1 \times 10^{8}$ & $4.5 \times 10^{5}$ & $99.93 \%$ & $6.1 \times 10^{8}$ & $4.7 \times 10^{4}$ & $99.99 \%$ \\
\hline 12 & $8.0 \times 10^{9}$ & $4 \times 10^{8}$ & $95 \%$ & $7.5 \times 10^{9}$ & $9 \times 10^{7}$ & $98.80 \%$ & $7 \times 10^{9}$ & $1 \times 10^{5}$ & $99.99 \%$ & $7 \times 10^{9}$ & $5 \times 10^{3}$ & $99.99 \%$ \\
\hline
\end{tabular}


The results indicated that improving efficacy of Salmonella numbers reduction by phages was done by raising the $\mathrm{MOI}$ and the optimal used $\mathrm{MOI}$ was 10 which achieved the target about reducing the cells by $98.20 \%$ after $4 \mathrm{hr}$. The results agreed with (Goode et al 2003) who used $10^{2}$ up to $10^{7}$ $\mathrm{MOI}$ on contaminated chicken skin and found that the reduction of Salmonella numbers increased according to increasing of MOI.

\section{REFERENCES}

Abd El-Aziz, D.M. 2013. Detection of Salmonella typhimurium in retail chicken meat and chicken giblets. Asian Pacific Journal of Tropical Biomedicine. 3(9), 678-681.

Abramia, G. Golijashvili, A., Rigvava, S., Natidze, M., Japarashvili, N., Makhatadze, N., Gverdtsiteli, L. and Eristavi, D. 2016. Bacteriophages against antibiotic resistant Salmone/la bacteria for the possible prevention and treatment of birds and cleanup of their water habitats. Journal Veterinary Science and Technology. 7, 1-6.

Ackermann, H.W., Tremblay, D. and Moineau, S. 2004. Long-term bacteriophage preservation. WFCC Newslett. 38, 35-40.

Adams, M.H. 1959. Bacteriophages. Interscience Publishers: New York. pp. 443-522.

Basdew, I. H. and Laing, M.D. 2014. Stress sensitivity assays of bacteriophages associated with Staphylococcus aureus, causal organism of bovine mastitis. African Journal of Microbiology Research. 8(2), 200-210.

Bell, C. and Kyriakides, A. 2002.Salmonella. In: Foodborne Pathogens: Hazards, Risk Analysis and Control. C.W. Blackburn and P.J. McClure, CRC Press. 307-335.

Borrego, J.J., Morifiigo, M.A., deVicente, A., Cornax, R. and Romero, P. 1987. Coliphages as an indicator of faecal pollution in water: Its relationship with indicator and pathogenic microorganisms. Water Research. 21, 14731480.

Connerton, P. L. and Connerton, I.F. 2005. Microbial treatments to reduce pathogens in poultry meat. Food Safety Control in the Poultry Industry. G. Mead, ed. Woodhead Publishing Ltd., Cambridge, UK. pp. 414-427.

De Lappe, N., Doran, G., O’Connor, J., O’Hare, C. and Cormican, M. 2009. Characterization of bacteriophages used in the Salmonella enterica serovar Enteritidis phage typing scheme. Journal of Medical Microbiology, 58, 86-93.
Doyle, M.P. and Erickson, M.C. 2006.Reducing the carriage of food-borne pathogens in livestock and poultry. Poultry Science. 85(6), 960973.

Feisal, A.A., Othman, B.A., El-Dougdoug, Kh. A. and Shalaby, H.F. 2013. Stability of Salmonella typhimurium bacteriophage to some physical and chemical factors. Egyptian Journal of Virology. 10,143-161.

Figrski, D.H. and Christensen, J.R. 1974. Functional characterization of the genes of bacteriophage TI. Virology. 69, 397-407.

Goode, D., Allen, V. M. and Barrow, P.A. 2003. Reduction of experimental Salmonella and Campylobacter contaminated of chicken skin by application of lytic bacteriophages. Applied and Environmental Microbiology. 69(8), 5032-5036.

Goodridge, L., Gallaccio, A. and Griffiths, W.M. 2001. Morphological, host range, and genetic characterization of two coliphages. Applied and Environmental Microbiology. 69, 53645371.

ljabadeniyi, O.A., Debusho, L.K., Vanderlinde, M. and Buys, E.M. 2011. Irrigation water as a potential preharvest source of bacterial contamination of vegetables. Journal of Food Safety. 31, 452-461.

Jończyk, E., Kłak, M., Międzybrodzki, R. and Górski, 2011.The influence of external factors on bacteriophages-review. Folia Microbiologica . 56, 191-200.

Kanjana, N. 2007. Isolation and partial characterization of Salmonella Typhi-specific bacteriophage KKU. Science Journal. 35(3), 162-169.

Kocharunchit, C.; Ross, T. and McNeil, D.L. 2009. Use of bacteriophages as biocontrol agents to control Salmonella associated with seed sprouts. International Journal of Food Microbiology. 128, 453-459.

Newell, D.G. and Fearnley, C. 2003.Sources of Campylobacter colonization in broiler chickens. Applied and Environmental Microbiology. 69(8), 4343-4351.

Ngangbam, A.K. and Devi, N.B.L. 2012. Molecular characterization of Salmonella bacteriophages isolated from natural environment and its potential role in phage therapy. Journal of Agriculture and Veterinary Science. 1(6), 711.

Othman, B.A. 1997. Isolation of lambida bacteriophage $\beta 4 \mathrm{EC}$ from sewage polluted drinking water. Proceeding of the $10^{\text {th }}$ Conference of Microbiology. pp. 78-88. 
Oxoid, 2006. The oxoid manual of culture media and other laboratory services. $9^{\text {th }}$ Edition, Complied by E.Y. Bridson pulished by Oxoid Limited, Wade Road, Basingstoke Hamphsire RG248PW, England.

Rattanachaikunsopon, P. and Phumkhachorn, P. 2012. Bacteriophage PPST1 isolated from hospital wastewater, a potential therapeutic agent against drug resistant Salmonella enterica subsp. enterica serovar Typhi. SalmonellaDistribution, Adaptation, Control Measures and Molecular Technologies, pp. 159-172.

Taj, M.K., Ling, J.X., Bing, L.L., Qi, Z., Taj, I., Hassani, T.M., Samreen, Z. and Yunlin, W. 2014. Effect of dilution, temperature and $\mathrm{pH}$ on the lysis activity of T4 phage against $E$. coli bl21. The Journal of Animal and Plant Sciences. 24 (4), 1252-1255.
Thung, T.Y., Premarathne, J.M.K.J.K., San Chang, W., Loo, Y.Y., Chin, Y.Z., Kuan, C. H., Tan, C.W., Basri, D.F., Radzi, C.W.J.W.M. and Radu, S. 2017. Use of a lytic bacteriophage to control Salmonella Enteritidis in retail food. LWT - Food Science and Technology. 78, 222-225.

Tiwari, B.R., Kim, S. and Kim, J. 2013. A virulent Salmonella enterica serovar Enteritidis phage SE2 with a strong bacteriolytic activity of planktonic and biofilmed cells. Journal of Bacteriology and Virology. 43(3), 186-194.

Turner, D. 2013. Characterization of three bacteriophages infecting serovars of Salmonella enterica. Ph.D., University of the West of England. p. 227.

Turner, D., Hezwani, M., Nelson, S., Salisbury, V. and Reynolds, D. 2012. Characterization of the Salmonella bacteriophage vB_SenS-Ent1. Journal of General Virology. 93, 2046-2056. 